\title{
Часова динаміка видів безхребетних в техноземах Нікополь- ського марганцеворудного басейну
}

\section{Анна Бабченко}

Державний вищий навчальний заклад

“Український державний хіміко-технологічний університет”, Дніпро, Україна

Адреса для листування: lineanna83@gmail.com

Отримано: 28.10.19; прийнято до друку: 20.12.19; опубліковано: 27.12.19

Резюме. У статті наведені результати дослідження динаміки видів наземних безхребетних у градієнті часу в техноземах Нікопольського марганцеворудного басейну. Дослідження проведене в Дослідницькому центрі Дніпровського державного аграрно-економічного університету (м. Покров, Україна) протягом 2013-2015 pp. Відбір зразків було зроблено на варіантах штучних грунтів (техноземів), які сформовані на лесоподібних суглинках, на червоно-бурих глинах, на сіро-зелених глинах, на технологічній суміші гірських порід та на лесоподібних суглинках із гумусованим верхнім шаром. Для дослідження просторово-часової мінливості чисельності, видового багатства та видового складу угруповання безхребетних у межах експериментального полігону, тварин було зібрано із застосуванням пасток Барбера. Досліджено сім груп безхребетних, близько пов'язаних із грунтовим середовищем та наземним рослинним покривом: (1) молюски (Mollusca: Gastropoda), (2) павуки (Chelicerata: Arachnida), (3) двопарноногі (Myriapoda: Diplopoda), (4) губоногі (Myriapoda: Chilopoda), (5) мокриці (Malacostraca: Isopoda: Oniscidea); (6) комахи (Tracheata: Isecta). Встановлено, що динаміка в часі протягом вегетаційного сезону чисельності найбільшої кількості видів безхребетних ділянки рекультивації описується бімодальною асиметричною моделлю (модель VII 3 переліку HOFJO). Бімодальність підкреслює важливість впливу біотичних (конкурентних) взаємодій між видами. Бімодальність може бути наслідком біологічної неоднорідності популяції та результатом міграційних процесів. Установлені типи часової динаміки безхребетних вказують на наявність складних та сформованих процесів регулювання чисельності тварин на порівняно молодих екологічних утвореннях, якими є техноземи. Часова динаміка видів безхребетних структурована в просторі та характеризується наявністю регулярних часових патернів, на основі яких встановлені такі фенологічні групи тварин: весняні, літні, літньо-осінні та осінні. Фітофаги переважають серед літньо-осінніх форм, а зоофаги серед осінніх та меншою мірою серед весняних або літніх. Відгук літніх форм у градієнті часу найчастіше описується симетричною дзвіноподібною моделлю V. Літньо-осінні форми характеризуються відгуками на час, які можуть бути описані моделями V, VI та VII. Весняні форми найчастіше мають розподіл, який найкраще описується моделями II та III. Для літніх форм характерна модель VII.

Ключові слова: безхребетні, рекультивація, угруповання, популяції, екологічна ніша, едафічні чинники, екологічні умови.

\section{Temporal dynamics of the invertebrates species of the tehnosols within Nikopol manganese ore basin}

\section{Anna Babchenko}

Ukrainian state university of Chemical Technology, Dnipro, Ukraine

Correspondence: lineanna83@gmail.com

Abstract. The article presents the results of the study of the dynamics of species of terrestrial invertebrates within the time gradient of the tehnosols within Nikopol manganese ore basin. Research conducted at the Research Center Dnieper State Agricultural and Economic University (Pokrov city, Ukraine) during 2013-2015. 
Sampling was done on anthropogenic versions of soils (technosols), which are formed on loesses-like loam to red-brown clay, in gray-green clay on the technological mix of rock and loam on loesses-like loam with humusrich layer of the soil top. To investigate the spatial and temporal variability of abundance, species richness and species composition of invertebrate communities within experimental test site, the animals were collected with the use of traps Barbera. The seven taxonomic groups of invertebrates were investigated which are closely related to the soil and land environment vegetation: (1) clams (Mollusca: Gastropoda), (2) spiders (Chelicerata: Arachnida), (3) dvoparnonohi (Myriapoda: Diplopoda), (4) centipede (Myriapoda: Chilopoda ), (5) woodlice (Malacostraca: Isopoda: Oniscidea); (6) insects (Tracheata: Isecta). It was found that the dynamics of the time during the growing season number greatest number of species of invertebrates land reclamation describes asymmetric bimodal model (model VII from the list HOFJO). Bimodalnist biotic stresses the importance of (competitive) interactions between species. Bimodal may be due to biological heterogeneity of the population and the resulting migration. The established types of temporal dynamics of invertebrates indicate the presence of complex and existing processes regulate the number of animals at the relatively young environmental entities, which are tehnosols. On the temporal dynamics of species of invertebrates structured in space and time are characterized by the presence of regular patterns on which the phenology, the following groups of animals: spring, summer, autumn, summer and autumn. Herbivores prevail among the summer-autumn forms of zoofagous - among autumn, and less of spring or summer. Reviewed summer gradient forms in time often described symmetric model V. The summer-autumn forms are characterized by feedback at the time, which can be described models of V, VI and VII. Spring forms often have a distribution model that best describes II and III.

Key words: invertebrates, reclamation, groups, populations, ecological niche, edaphic factors, environmental conditions

\section{ВСТУП}

Глибокі підземні гірничі розробки здійснюють значний вплив на ландшафт, трансформуючи природні ландшафти та залишаючи ландшафти в зміненому стані [25, $31,43,42]$. Ландшафтна трансформація внаслідок відкритих гірничих розробок призводить до сильних змін у структурі наземного покриву, водотоків, мікроклімату, землекористуванні, угруповань живих організмів [22, 41]. Технічний та біологічний етапи рекультивації $\epsilon$ важливими для менеджменту порушених ландшафтів [23, 24, 39]. Технічний етап рекультивації значно трансформує середовище та вповільнює сукцесійну динаміку угруповань жуків [25]. Принцип екологічної ніші повинен застосовуватися для теоретичного обгрунтування процесу відновлення земель, порушених гірничими розробками [48]. Розподіл патернів грунтової макрофауни сильно залежить від розвитку грунту після рекультивації [16]. Сукцесія тваринних угруповань після рекультивації зазнає впливу різноманіття рослинних угруповань $[6,21]$. Угруповання жуків рекультивованих місцеперебувань визначається рослинним та грунтовим покривом [24]. Встановлено, що видове багатство угруповань комах рекультивованих територій зазнає впливу таких чинників середовища, як вік дерев, рослинне різноманіття та хімізм грунту $[6,12]$. Мікрокліматичні умови, вологість, рослинний покрив та структура деревостану $\epsilon$ найважливішими змінними середовища, які впливають на угруповання безхребетних на територіях, які залишилися після відкритих гірничих розробок бурого вугілля [22]. Епігейні безхребетні на ранніх стадіях колонізації техноземів представлені сукцесією, яка опосередковано пов'язана зі змінами грунтових параметрів [20]. Застосування органічних відходів у поєднанні з ревегетацією призводить до швидкого зростання чисельності жуків [30]. Малі за розміром види Carabidae, які мають високу адаптивну здатність та високу екологічну пластичність, домінують у рекультивованих землях [29]. Гіпотеза «ширини ніші» за Дж. Брауном [5] була застосована для того, щоб пояснити структуру локальних угруповань нерекультивованих ділянок [4].

Дослідження екологічних режимів сільськогосподарської рекультивації земель у Дослідницькому центрі Дніпровського державного аграрно-економічного університету (м. Покров, Україна) ведуться $360-x$ років минулого століття [50]. У рекультоземах Нікопольського марганцеворудного басейну було досліджено закономірності просторового варіювання грунтової макрофауни [49], грунтових мікромолюсків [45]. Слід відзначити, що у світовій науковій літературі ще мало досліджені характеристики ніш наземних артропод $\epsilon$ все ще рідкісними [14] та відсутні відомості про особливості відгуків у часі для груп наземних безхребетних на вплив чинників середовища рекультивованих територій. Тому дослідження часової динаміки видів безхребетних в техноземах $\epsilon$ актуальною проблемою. 
Науковий вісник Східноєвропейського національного університету імені Лесі Українки. Серія: Біологічні науки, 2019, 4 (388)

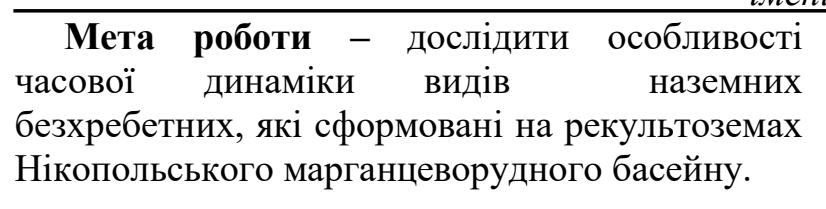

\section{МАТЕРІАЛИ Й МЕТОДИ ДОСЛІДЖЕНЬ}

Дослідження проведене у Дослідницькому центрі Дніпровського державного аграрноекономічного університету (м. Покров, Україна) протягом 2013-2015 pp. Експериментальний полігон для дослідження оптимальних режимів сільськогосподарської рекультивації був створений в 1968-1970 pp. Відбір зразків було зроблено на варіантах штучних грунтів (техноземів), які сформовані на лесоподібних суглинках, на червоно-бурих глинах, на сіро-зелених глинах, на технологічній суміші гірських порід та на лесоподібних суглинках з гумусованим верхнім шаром (70 см) (географічні координати полігону 47³8'55.24 "півн. шир., 3408'33.30" схід. довг.). Для дослідження просторовочасової мінливості чисельності (кількості зібраних особин), видового багатства та видового складу угруповання безхребетних у межах експериментального полігону, тварин було зібрано з застосуванням пасток Барбера. Ми дослідили сім груп безхребетних, близько пов'язаних із грунтовим середовищем та наземним рослинним покривом: (1) молюски (Mollusca: Gastropoda), (2) павуки (Chelicerata: Arachnida), (3) двопарноногі (Myriapoda: Diplopoda), (4) губоногі (Myriapoda: Chilopoda), (5) мокриці (Malacostraca: Isopoda: Oniscidea); (6) комахи (Tracheata: Isecta). Загалом 60 пасток було застосовано одночасно в кожному періоді для відбору проб. На кожному майданчику було розміщено по три пастки на вершинах трикутника 3 довжиною сторони 3 м [10, 38]. 3 кінця квітня і до початку жовтня через кожні 7 9 діб здійснювали виїмку з пасток.

Вміст доступної для рослин вологи (ДДВ, мм у метровому шарі грунту), опади (мм), швидкість вітру (м/с), атмосферна температура (добовий мінімум, добовий максимум, середньодобова температура, $\left.{ }^{\circ} \mathrm{C}\right)$, атмосферна вологість (\%), атмосферний тиск (гПа) були застосовані як екологічні предиктори. 3 метою дослідження були використані дані 3 Нікопольської метеостанції. Для кожного часу експозиції були розраховані такі параметри середовища: загальна сума опадів за період, середнє значення доступної для рослин вологи, швидкості вітру, атмосферної температури, вологості й тиску [33].
Визначення молюсків здійснено за Н. В. Гураль-Сверловою та Р. І. Гуралем [19], літобіоморфні багатоніжки визначені за Н. Т. Залеською [46], сколопендроморфні - за Н. Т. Залеською та А. А. Шилейко [47], геофіломорфні - за Л. Бонато та співавт. [2], двопарноногі багатоніжки - за Н. Г. Чорним та С. І. Головачем [8], жуків - за визначником [27].

Параметри моделей Хуізмана, Ольфа та Фреско було оцінено в статистичній програмі $\mathrm{R}$ (v. 3.3.1) (R Developmental Core Team, 2019) 3 застосуванням пакету “еHOF” ([28] version 3.2.2). Множинні ординаційні техніки було застосовано для аналізу просторово-часового варіювання у видовому складі комплексу безхребетних. Фактори середовища були підігнані до осей СА-ординації за допомогою функції enfit бібліотеки vegan (Oksanen et al., 2018). Для статистичних аналізів ми застосовували відповідні процедури для Statistica (Version 12.0, StatSoft Inc., http://www.statsoft.com) або R (version 3.5.2; R Core Team, 2018).

\section{РЕЗУЛЬТАТИ ТА ЇХ ОБГОВОРЕННЯ}

Розподіл зважених за чисельністю видів тварин порядкових номерів діб з початку року $є$ полімодальним та може бути представлений як суміш чотирьох нормальних розподілів (Kolmogorov-Smirnov $d=0.029, p=0.99$ ) (рис. 1).

Складова 3 середнім 128,4 діб та середньоквадратичним відхиленням 8,5 становить $30.3 \%$ від варіювання суміші. Складова 3 середнім 166,7 діб та середньоквадратичним відхиленням 18,2 становить $19.2 \%$ від варіювання суміші. Складова 3 середнім 206,5 діб та середньоквадратичним відхиленням 17,8 становить $39.7 \%$ від варіювання суміші. Складова 3 середнім 256,2 діб та середньоквадратичним відхиленням 11,9 становить $10.8 \%$ від варіювання суміші. Розподіл зважених середньоквадратичних оцінок за порядковими номерами діб може бути описаний нормальним розподілом (Kolmogorov-Smirnov $d=0.049, p=0.69$ ). Отже, аналіз властивостей розподілу оцінки оптимальних термінів активності безхребетних вказує на вірогідну наявність чотирьох однорідних за часом активності груп тварин. Максимум групової активності, який припадає на 128 добу 3 
Часова динаміка видів безхребетних в техноземах Нікопольського марганиеворудного басейну

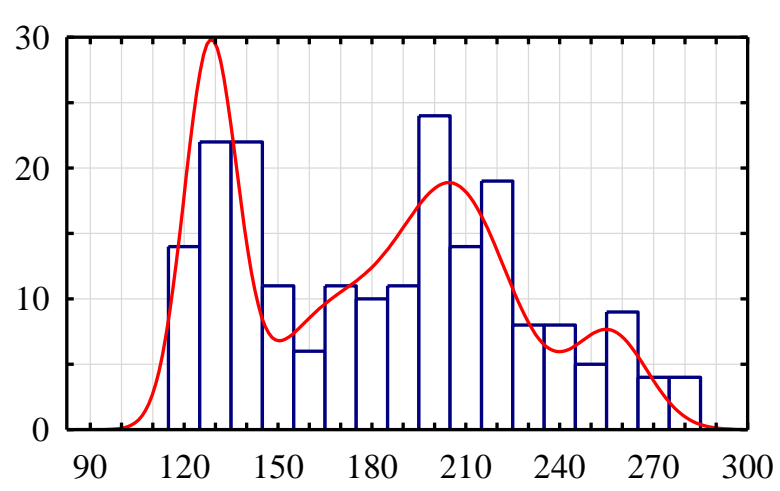

A

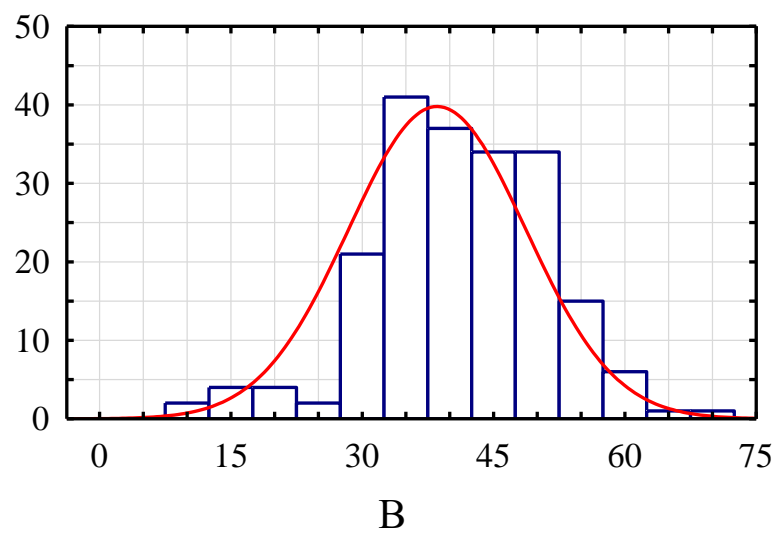

Рис. 1. Гістограми розподілів зважених за чисельністю видів тварин порядкових номерів діб з початку року (A) та зважених оцінок середньоквадратичного відхилення цъього показника $(B)$

початку року відповідає наявності тварин 3 весняним піком активності. Активність на 166 добу відповідає тваринам 3 піком активності наприкінці весни або на початку літа. Літня активність відповідає піку 206 діб, а пізньолітня-осіння активність відповідає піку 256 діб.

Часову й просторову динаміку чисельності популяції та різноманіття угруповання можна пояснити на основі теорії ніші [40]. Ця теорія прогнозує, що розподіл виду зазнає впливу внаслідок відмінностей між оптимумом виду та факторами середовища [26]. Наші одержані результати свідчать про те, що характер відгуку видів у градієнті часу можна описати шістьма із сімох HOFJO-моделей (рис. 2). Вимірювання властивостей ніші торкається таких проблем, як проблема діапазону, проблема відстаней та проблема нелінійності [9]. Форма кривої відгуку має теоретичне й практичне значення [1]. Ніша може бути кількісно описана за допомогою iii позиції та ширини [17]. Такі параметри відгуку виду, як оптимум або ширина ніші, залежать від форми моделі [28] та можуть бути застосовані для пояснення екологічної поведінки видів [35]. Усі атрибути моделі, за винятком оптимуму, зазнають значного впливу властивостей множини даних, ось чому складно встановити реальні характеристики ніші видів [35]. Не встановлено відповідності відгуку видів тільки моделі I, що вказує на значну структурованість динаміки чисельності видів безхребетних у часі. Найчастіше відгук видів описують бімодальною асиметричною моделлю VII. Це вказує на наявність двох нерівних піків активності у більшості видів. Такий результат робить неможливим виділення фенологічно однорідних груп видів безхребетних за результатами розподілу оптимальних термінів за оцінкою, за методом середнього зваженого. Бімодальність може бути результатом впливу біотичних (конкурентних) взаємодій між видами [7]. Вона також може виникати внаслідок біологічної неоднорідності популяції може бути представлена різними стадіями розвитку [26]. Біомодальність також можна розглядати як результат міграційних процесів, коли другий спалах чисельності виду виникає внаслідок переселення (імміграції), а не процесу розмноження. Наступним за значимістю типом відгуку $\epsilon$ такий, який описується моделлю III. Для цього типу характерне значне за тривалістю у часі плато рівного преферендуму, який обмежується різким зниженням чисельності. Найчастіше таке зниження відбувається наприкінці літа, але трапляються випадки, коли з'являється активність виду навесні i триває на порівняно стійкому рівні протягом усього вегетаційного періоду.

Такий тип часової динаміки вказує на загалом досить сприятливі умови існування багатьох видів в умовах техноземів. Не можна також виключати явища еміграції-імміграції у формуванні такого типу часової динаміки. Можна припустити, що стійке плато чисельності досягається за рахунок еміграції в моменті тенденції до збільшення чисельності та 


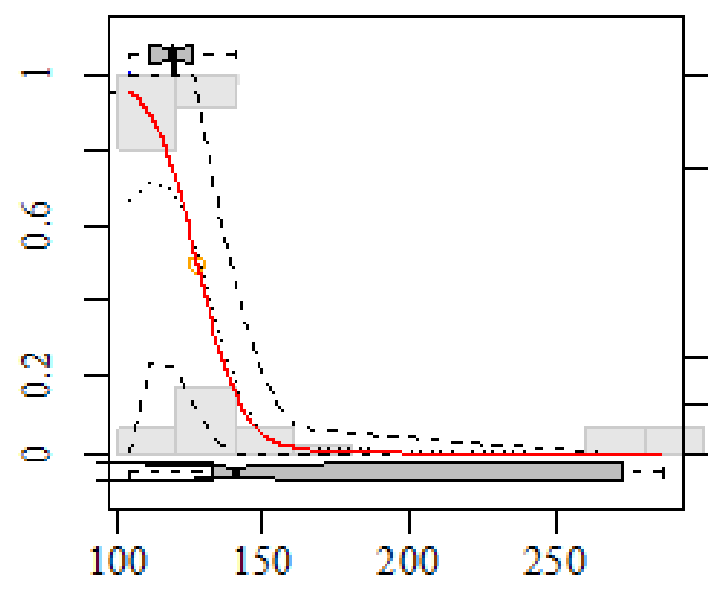

A

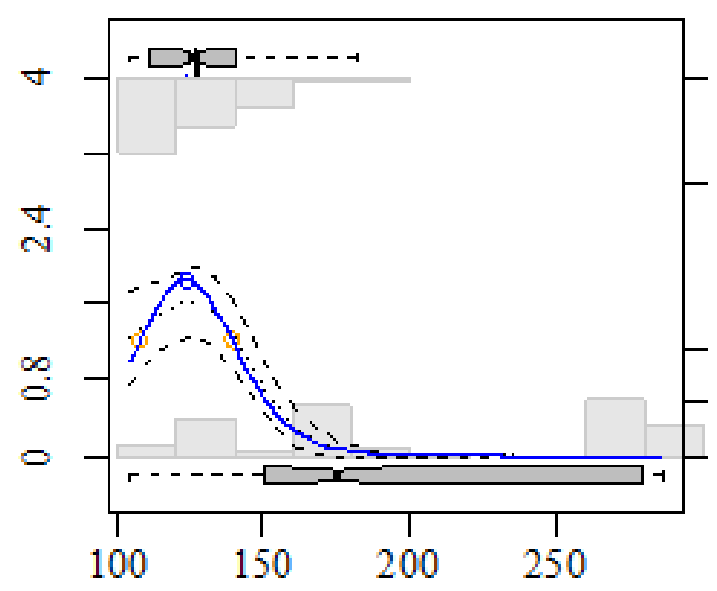

$\mathrm{C}$

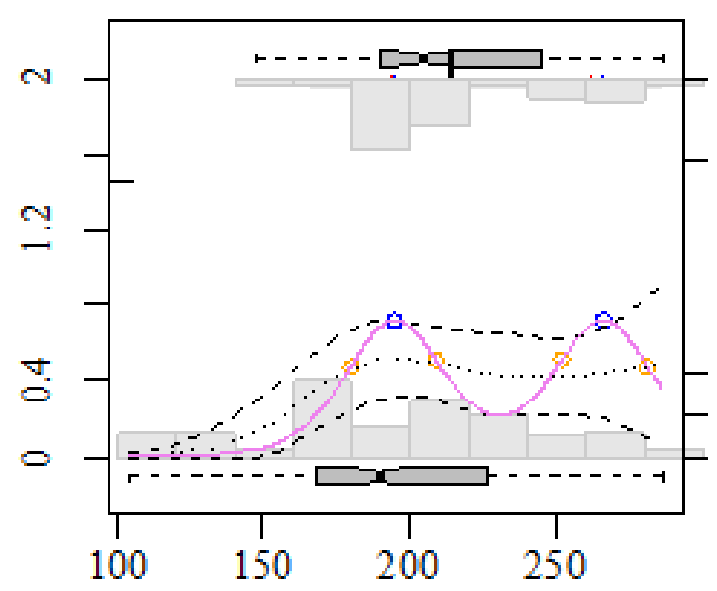

$E$

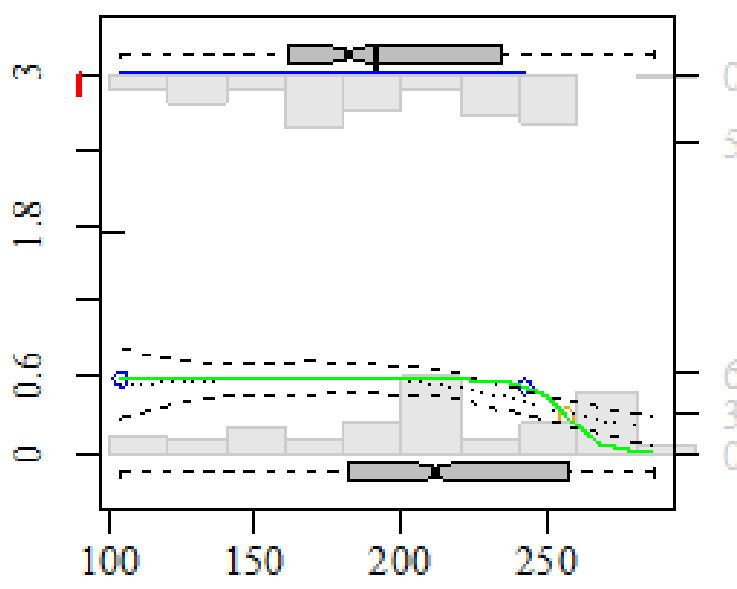

B

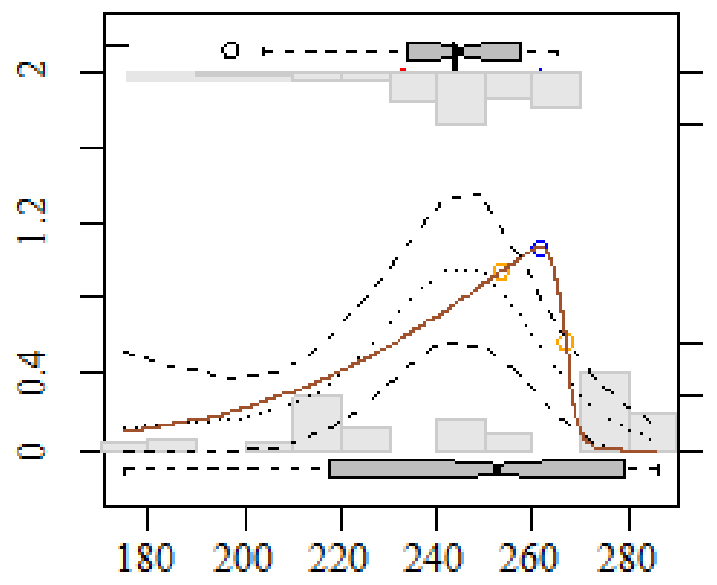

D

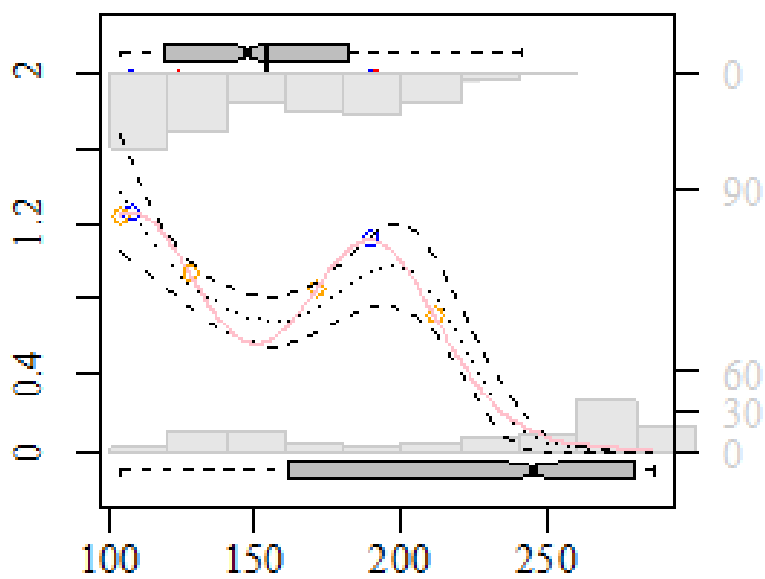

$\mathrm{F}$

Рис. 2. Різноманітні моделі відгуку чисельності видів у градієнті часу. Ось абсиис - порядок діб з початку року; ось ординат - кількість індивідуумів. НОFJO-моделі: A - модель II (Agroеса сиргеа),

$B$ - модель III (Agriotes gurgistanus), $C$-модель IV (Dorcadion tauricum), D-модель V (Licinus cassideus), E-модельVI (Mylabris polymorpha), F-модель VII (Onthophagus ovatus) 
Часова динаміка видів безхребетних в техноземах Нікопольського марганщеворудного басейну

навпаки, локальне зменшення чисельності компенсується імміграційними процесами. Загалом такий тип часової динаміки може вказувати на наявність складних та сформованих процесів регулювання чисельності безхребетних [42] на порівняно молодих екологічних утвореннях, якими $є$ техноземи [49]. Тип моделі IV за своєю здатністю описувати часову динаміку чисельності безхребетних значно поступається усім іншим з розглянутих моделей. Симетрична та унімодальна модель IV $\epsilon$ базовою для багатьох підходів щодо оцінки оптимуму й толерантності видів, зокрема метод зваженого середнього, логістична регресія та аналіз відповідностей. Як свідчать одержані результати, припущення, які лежать в основі вказаних підходів, виконуються в обмеженій кількості випадків, тому точність відповідних оцінок може бути вкрай сумнівною. Отже, часова динаміка видів безхребетних є добре структурованою, та відгуки видів у градієнті часу $\epsilon$ переважно асиметричними та біомодальними. Це дозволяе припустити значну роль у формуванні часових патернів як впливу комплексу абіотичних факторів, так $\mathrm{i}$ значної ролі біотичних взаємодій [11]. Для оцінки такого роду чинників був проведений детрендовий аналіз відповідностей (табл. 1). Як показали результати, довжина найбільшої осі, одержаної внаслідок детрендового аналізу відповідностей, становить 2,45 та переважає довжину 2, що засвідчує обгрунтованість застосування відповідної процедури. Ширина ніші - це дистанція в межах ніші уздовж деякої конкретної лінії у нішевому просторі [9]. Ширина ніші є суттєво зворотною екологічній спеціалізації [32]. Було показано, що різні

Таблиця 1

Оцінка впливу факторів середовища, часових і просторових змінних та типів техноземів на результати DCA-ординації

\begin{tabular}{|c|c|c|c|c|c|c|c|}
\hline \multirow[b]{2}{*}{$\begin{array}{c}\text { Предиктор } \\
\text { и }\end{array}$} & \multicolumn{4}{|c|}{ Осі, довжина осі } & \multirow[b]{2}{*}{$R^{2}$} & \multirow[b]{2}{*}{$\operatorname{Pr}(>\mathbf{r})$} & \multirow{2}{*}{$\begin{array}{c}\text { Коди } \\
\text { статистичної } \\
\text { вірогідності } \\
\end{array}$} \\
\hline & $\begin{array}{c}\text { DCA1, } \\
2.45 \\
\end{array}$ & $\begin{array}{c}\text { DCA2, } \\
1.78 \\
\end{array}$ & $\begin{array}{c}\text { DCA3, } \\
1.78 \\
\end{array}$ & $\begin{array}{c}\text { DCA4, } \\
1.83 \\
\end{array}$ & & & \\
\hline \multicolumn{8}{|c|}{ Кліматичні предиктори } \\
\hline Опади & 0.52 & -0.19 & -0.72 & -0.43 & 0.06 & 0.001 & **** \\
\hline Biтер & 0.19 & 0.19 & 0.93 & 0.24 & 0.10 & 0.001 & $* * *$ \\
\hline $\mathrm{T}_{\min }$ & -0.49 & -0.23 & -0.30 & -0.79 & 0.07 & 0.001 & $* * *$ \\
\hline $\mathrm{T}_{\max }$ & -0.30 & -0.26 & -0.61 & -0.69 & 0.09 & 0.001 & $* * *$ \\
\hline $\mathrm{T}$ & -0.42 & -0.26 & -0.49 & -0.72 & 0.08 & 0.001 & $* * *$ \\
\hline Вологість & 0.61 & 0.26 & 0.56 & 0.50 & 0.08 & 0.001 & $* * *$ \\
\hline Тиск & -0.25 & 0.23 & 0.89 & 0.30 & 0.19 & 0.001 & $* * *$ \\
\hline RAW & 0.79 & -0.08 & -0.51 & -0.31 & 0.94 & 0.001 & $* * *$ \\
\hline \multicolumn{8}{|c|}{ Time predictors } \\
\hline AEM_1 & -0.80 & -0.11 & -0.58 & -0.13 & 0.81 & 0.001 & $* * *$ \\
\hline AEM_2 & 0.19 & 0.22 & 0.62 & 0.73 & 0.08 & 0.001 & $* * *$ \\
\hline AEM_3 & -0.35 & -0.07 & -0.02 & -0.93 & 0.01 & 0.015 & $*$ \\
\hline AEM_4 & 0.67 & 0.66 & -0.06 & -0.33 & 0.01 & 0.017 & $*$ \\
\hline \multicolumn{8}{|c|}{ Spatial predictors } \\
\hline Spat_1 & 0.14 & -0.79 & 0.45 & 0.40 & 0.44 & 0.001 & $* * *$ \\
\hline Spat_2 & 0.00 & 0.90 & 0.43 & -0.11 & 0.51 & 0.001 & $* * *$ \\
\hline Spat_3 & 0.03 & -0.21 & 0.47 & -0.86 & 0.44 & 0.001 & $* * *$ \\
\hline Spat_4 & -0.06 & -0.19 & -0.10 & -0.97 & 0.13 & 0.001 & $* * *$ \\
\hline Spat_5 & 0.05 & 0.00 & 0.53 & -0.85 & 0.08 & 0.001 & $* * *$ \\
\hline Spat_6 & 0.19 & 0.40 & 0.56 & 0.70 & 0.02 & 0.001 & $* * *$ \\
\hline \multicolumn{8}{|c|}{ Tecnosols types, $R^{2}=0.19, p<0.001$} \\
\hline GG & -0.02 & -0.31 & -0.05 & -0.12 & - & - & - \\
\hline LL & 0.04 & -0.26 & 0.12 & 0.13 & - & - & - \\
\hline $\mathrm{PZ}$ & 0.02 & 0.28 & -0.17 & 0.23 & - & - & - \\
\hline RB & -0.02 & -0.15 & -0.05 & -0.06 & - & - & - \\
\hline TM & -0.05 & 0.43 & 0.10 & -0.28 & - & - & - \\
\hline
\end{tabular}

Примітка. Коди статистичної вірогідності: ‘***’ $-<0.001$; ‘**’ $-<0.01$; ‘*’ $-<0.05$ 
аспекти розміру ніші,такі як кліматична толерантність, ширина спектру оселищ або ширина трофічного спектру, впливають на розмір ареалу виду [15]. Термін спеціалізація застосовують для різних рівнів біологічної організації (особини, види, популяції й угруповання) та вимірюють на різних просторових рівнях [11]. Для інтерпретації чотирьох осей, виокремлених внаслідок аналізу, ми застосували процедуру підгонки зовнішніх чинників.

Процедура показала, що кліматичні предиктори, часові, просторові змінні та тип технозему $є$ значними факторами, які структурують угруповання безхребетних. Вологість грунту - найвагоміший фактор структурування угруповання, вона здатна пояснити $94 \%$ варіювання виділених осей. Найбільшу роль вологість грунту відіграє у формуванні динаміки осей 1 та 3, дещо меншу роль - у формуванні осі 4 та мінімальну - для осі 2. Динаміка атмосферного тиску також $є$ вкрай важливою. Можна припустити, що тиск атмосферного повітря має значний вплив на конденсацію повітряної вологи і в такий спосіб впливає на реальний водний режим техноземів. Також велике значення має швидкість вітру. Безумовно, швидкість випаровування 3 поверхні грунту або поверхні рослин дуже залежить від швидкості вітру. Опади, температура, вологість $є$ статистично вірогідними чинниками динаміки угруповання безхребетних [49], але за нашими даними роль цих факторів дещо менша за раніше зазначених. Динаміка як угруповання безхребетних, так і перебігу екологічних умов, суттєвим чином структурована в часі, про що й свідчать ознаки предикторів часових змінних. Найбільшу частину дисперсії угруповання здатна пояснити змінна AEM_1, яка моделює монотонний сигмоїдний тренд. Слід відзначити, що роль цієї часової змінної $є$ найважливішою для тих осей, що i роль вологості грунту. Це дозволяє припустити, що динаміка вологості грунту має чітко виражену сезонну складову. Роль інших змінних часу (24) $\epsilon$ статистично вірогідною, але суттєво меншою порівняно зі змінною 1. Очевидно, роль коливальних процесів більшої частоти, які позначають АЕМ-змінні більшого порядкового номера, значно поступається загальносезонному тренду.

Отже, часові змінні добре моделюють фенологічну динаміку, з якою погоджені зміни абіотичних факторів та динаміка угруповань безхребетних. Динаміка угруповання також демонструє наявність просторових патернів, які моделюються просторовими змінними. Ці результати підтверджують раніше одержані відомості для грунтової макрофауни в техноземах [45]. За нашими результатами просторові змінні здатні пояснити від 2 до $51 \%$ варіювання угруповання безхребетних. Найбільше значення мають низкочастотні просторові змінні (1-3), які моделюють просторові коливальні процеси невеликої частоти. Більш високочастотні процеси $є$ статистично вірогідними, але відіграють меншу роль у часовій динаміці угруповання. Природа таких трендів може бути або нейтральною, або наслідком просторової структурованості екологічних умов, які, у свою чергу, впливають на динаміку угруповання [18]. До такого типу умов можуть належати ті, що безпосередньо не виміряні у цьому дослідженні [13].

Особливості динаміки угруповання безхребетних залежать від специфіки техноземів, про що свідчить статистично значимий вплив змінної, яка це позначає. Тип технозему здатний пояснити $19 \%$ варіювання осей, виділених внаслідок детрендового аналізу відповідностей. Найбільшу роль типу технозему виявлено стосовно осей 2-4. Для осі 1 цей вплив не значний, тому цю ось можна ідентифікувати як загальний тренд мінливості угруповання, який не дуже залежить від типу технозему. Ось DCA 1 віддзеркалює закономірну зміну угруповання безхребетних у часі, тоді як DCA 2 є практично нечутливою до часу, який представлений як монотонний градієнт. Очевидно, що часова складова мінливості угруповання, яка стоїть за DCA 2, має більш складний характер як сукупність коливальних процесів різної частоти. DCA 3 у період з початку вегетації до 180 доби вказує на практично монотонну динаміку угруповання 3 плином часу, а після зазначеного часу формується «петля» як наслідок формування трендів мінливості, які описуються DCA 4 та залежні від часу.

Оцінки оптимуму й толерантності видів, одержані різними підходами, дають загалом скорельовані результати, але деколи можна встановити принципові розбіжності. Ці розбіжності зумовлені різноманіттям типів відгуку видів у градієнті часу, які неможливо поєднати для аналізу в межах єдиного методичного підходу. Метод середнього зваженого та регресійний метод дають досить близькі оцінки оптимального часового періоду для видів. Оцінки за моделями 3 HOFJOпереліку дають за умов загальної позитивної 
Часова динаміка видів безхребетних в техноземах Нікопольського марганиеворудного басейну

кореляції регулярні відхилення оцінок порівняно 3 двома попередніми методами. Ці відхилення стосуються видів, які займають як маргінальні позиції, так і центральні. Розбіжності оцінок оптимуму для маргінальних видів є досить зрозумілими. Крайові позиції видів найчастіше деформують симетрію відгуку видів, внаслідок чого вимоги симетрії для застосування методів середнього зваженого або регресійного порушуються. Концентрацію оцінок оптимуму, які наближені до центральної частини діапазону при застосуванні HOFJOпереліку, певною мірою складно визначити.

Оцінка оптимуму за методом СА не дає добрих результатів, оскільки градієнт часу поступається за значимістю 3 іншими факторами та крім того, часова складова варіювання має складну мультімасштабну структуру. Тому зв’язати часові зміни з однією 3 осей ординаційної процедури неможливо, тим більше, що обмеження, які на дані накладає застосовування такої процедури, більшою мірою не виконуються.

CСА-аналіз 3 часом у якості предиктора та змінними простору, кліматичних умов і типу технозему в якості коваріат дозволяє вирішити декілька завдань. Це виокремлення впливу інших суттєвих чинників на варіювання угруповання безхребетних та оцінка впливу на залишок змінної, яка цікавить, - у нашому випадку це час. Тобто цей аналіз дозволяє зробити запит на встановлення характеру впливу саме часу i саме його монотонної складової на угруповання. Саме для монотонного градієнту мають сенс такі показники, як оптимум і толерантність. Такий підхід дозволяє зробити оцінку для «ідеалізованого» угруповання, на яке не здійснює дестабілізуючий вплив навколишнє середовище та простір.

Порівняння оцінок оптимуму за ССАаналізом 3 іншим вказує, що цей підхід дозволяе значно розширити значення варіювання угруповання на початкових етапах розвитку протягом вегетаційного періоду. Оцінки, які практично збігаються або не суттєво відрізняються у весняний період за іншими підходами, значно диференційовані за результатами ССА-аналізу. Порівняння оцінок толерантності за різними методами вказує на значні розбіжності.

Порівняння оцінок оптимуму, як i толерантності 3 урахуванням типів моделей 3 HOFJO-переліку, вказує на те, що для правильності оцінок дуже важливою умовою є виконання обмежень, які накладають на структуру вихідних даних застосовувані методи. Симетричний характер відгуку засвідчує збіг оцінок за різними методами. Відхилення законів відгуку від ідеалізованих призводять до суттєвого здвигу оцінок. Але важливою особливістю $є$ не тільки характер відгуку, але й той факт, що цей відгук $\epsilon$ комплексною реакцією виду на сукупну дію факторів різної природи. Причому стосовно фактору часу інші фактори можуть мати більш суттєве значення. Тому процедура врахування впливу інших чинників $є$ необхідною умовою одержання правильної оцінки оптимуму та толерантності виду.

Отже, варіювання угруповання безхребетних відбувається у різних часових вимірах та поряд 3 монотонною часовою динамікою відбуваються часові процеси різних частотних характеристик. Для оцінки ролі часу у структуруванні угруповання нами був проведений пояснювальний аналіз відповідностей угруповання зі АЕМ-змінними часу в якості предикторів. Було встановлено, що часові змінні пояснюють $15.2 \%$ варіації угруповання $(F=12.2, p<0.001)$. Нами виділено чотири просторово-детермінованих CCA-осі, які характеризуються певним комплексом коливальних процесів (рис. 3). ССА-ось 1 вказує на загальний монотонний тренд мінливості структури угруповання протягом року. Регресійний аналіз (табл. 2) вказує на те, що АЕМ-змінна $1 \epsilon$ найважливішим предиктором цієї осі. Як зазначали раніше, АЕМ-змінна 1 моделює монотонний часовий тренд. Слід відзначити, що ось 1 визначається також коливальними процесами більш високої частоти, про що свідчить статистично вірогідні регресійні коефіцієнти для таких предикторів, як АЕМзмінні 2-4, 7, 14, 21 і 25. Але роль цех предикторів значно менша, ніж значення АЕМзмінної 1.

ССА-ось 2 вказує на наявність у динаміці структури угруповання двох локальних максимумів - на початку літа та наприкінці літа або на початку осені. У різні роки дати цих максимумів можуть зміщуватися на більш ранній або на більш пізній період та можуть змінювати рівень прояву цих максимумів. Найбільш важливим предиктором ССА-осі 2 є змінна AEM_3, але складність динаміки цієї осі підкреслює статистична значимість у якості предикторів широкого переліку АЕМ-змінних.

ССА-ось 3 чутлива до драматичних перебудов структури угруповання безхребетних наприкінці літа або на початку осені. 
Науковий вісник Східноєвропейського начіонального університету імені Лесі Украӥнки. Серія: Біологічні науки, 2019, 4 (388)
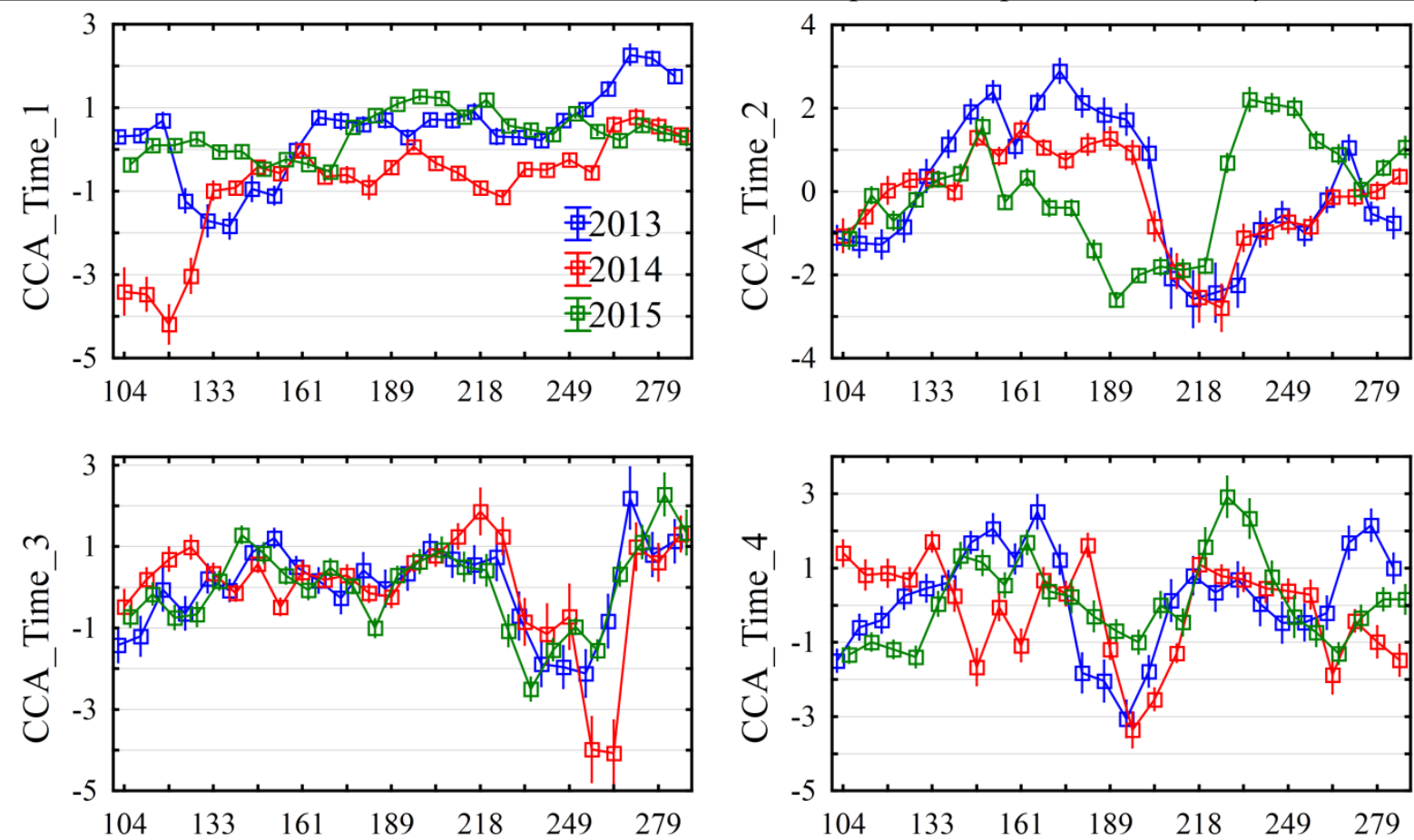

Рис. 3. Складові часових трендів угруповання безхребетних, представлені динамікою у часі ССА-осей 1-4, одержсаних внаслідок аналізу відповідностей угруповання безхребетних зі змінними часу в якості пояснювальних змінних та просторовими змінними, змінними властивостей середовища та типів техноземів у якості коваріат (умовних змінних)

Таблиия 2

Результати регресійного аналізу залежності осей, які виділені внаслідок ССА-аналізу від змінних часу (регресійні $\beta$-коефіціснти \pm ст. помилка, показані коефіціснти, відібрані після процедури forward stepwise selection $3 p<0.05$ )

\begin{tabular}{|c|c|c|c|c|}
\hline $\begin{array}{c}\text { Чacoвi } \\
\text { предиктори }\end{array}$ & $\begin{array}{c}\text { CCA-ocь 1, } \\
\boldsymbol{R}_{a d j}^{2}=\mathbf{0 . 3 4}, \\
\boldsymbol{p}<\mathbf{0 . 0 0 1}\end{array}$ & $\begin{array}{c}\text { CCA-ocь 2, } \\
\boldsymbol{R}_{a d j}^{2}=\mathbf{0 . 3 5}, \\
\boldsymbol{p}<\mathbf{0 . 0 0 1}\end{array}$ & $\begin{array}{c}\text { CCA-ocь 3, } \\
\boldsymbol{R}_{\text {adj }}^{2}=\mathbf{0 . 3 5}, \\
\boldsymbol{p}<\mathbf{0 . 0 0 1}\end{array}$ & $\begin{array}{c}\text { CCA-ocь 4, } \\
\boldsymbol{R}_{\text {adj }}^{2}=\mathbf{0 . 3 5}, \\
\boldsymbol{p}<\mathbf{0 . 0 0 1}\end{array}$ \\
\hline AEM_1 & $0.52 \pm 0.02$ & $-0.11 \pm 0.02$ & $-0.06 \pm 0.02$ & - \\
\hline AEM_2 & $-0.13 \pm 0.02$ & $-0.04 \pm 0.02$ & $-0.11 \pm 0.02$ & $0.05 \pm 0.02$ \\
\hline AEM_3 & $0.13 \pm 0.02$ & $0.49 \pm 0.02$ & $0.22 \pm 0.02$ & $0.10 \pm 0.02$ \\
\hline AEM_4 & $0.15 \pm 0.02$ & $-0.10 \pm 0.02$ & $0.22 \pm 0.02$ & $-0.35 \pm 0.02$ \\
\hline AEM_5 & - & $-0.15 \pm 0.02$ & $0.47 \pm 0.02$ & - \\
\hline AEM_6 & - & $-0.15 \pm 0.02$ & $0.19 \pm 0.02$ & $0.33 \pm 0.02$ \\
\hline AEM_7 & $-0.06 \pm 0.02$ & - & - & $0.24 \pm 0.02$ \\
\hline AEM_8 & - & $0.15 \pm 0.02$ & $-0.09 \pm 0.02$ & $-0.07 \pm 0.02$ \\
\hline AEM_9 & - & $0.04 \pm 0.02$ & $-0.04 \pm 0.02$ & $-0.14 \pm 0.02$ \\
\hline AEM_10 & - & - & $-0.05 \pm 0.02$ & - \\
\hline AEM_11 & - & $-0.05 \pm 0.02$ & $-0.04 \pm 0.02$ & - \\
\hline AEM_12 & - & $0.10 \pm 0.02$ & $0.13 \pm 0.02$ & $0.05 \pm 0.02$ \\
\hline AEM_13 & - & $-0.05 \pm 0.02$ & $0.04 \pm 0.02$ & $0.05 \pm 0.02$ \\
\hline AEM_14 & $-0.04 \pm 0.02$ & $0.07 \pm 0.02$ & $-0.12 \pm 0.02$ & $-0.06 \pm 0.02$ \\
\hline AEM_15 & - & - & $0.08 \pm 0.02$ & - \\
\hline AEM_16 & - & - & & $0.06 \pm 0.02$ \\
\hline AEM_17 & - & - & $-0.08 \pm 0.02$ & - \\
\hline AEM_18 & - & - & $0.11 \pm 0.02$ & - \\
\hline AEM_19 & - & - & $-0.07 \pm 0.02$ & $-0.06 \pm 0.02$ \\
\hline AEM_20 & - & - & $-0.07 \pm 0.02$ & $-0.04 \pm 0.02$ \\
\hline AEM_21 & $-0.04 \pm 0.02$ & $-0.06 \pm 0.02$ & - & $0.05 \pm 0.02$ \\
\hline AEM_22 & - & - & $0.05 \pm 0.02$ & - \\
\hline AEM_24 & - & - & - & $-0.07 \pm 0.02$ \\
\hline AEM_25 & $-0.05 \pm 0.02$ & - & - & - \\
\hline
\end{tabular}


Часова динаміка видів безхребетних в техноземах Нікопольського марганщеворудного басейну

Щорічна засуха у цей період сезону вимагає фенологічних адаптацій. ССА-ось 4 вказує на ще більш високочастотні коливання у динаміці угруповання безхребетних.

Отже, для видів безхребетних, які складають угруповання, можна виділити патерни мінливості, які мають характер типових трендів фенологічних змін в угрупованні. Ці зміни повторювані з року в рік, хоч деякі кількісні особливості можуть змінюватися відповідно до умов певного року. Ці фенологічні зміни результат погодженої динаміки угруповання у відповідь на регулярні зміни абіотичних умов.

АЕМ-підхід дає можливість моделювати складні часові патерни, які значно виходять за межі типових моделей відгуків видів на вплив факторів середовища [3]. Виділені CСА-осі можуть мати проекції не тільки на точки відбору проб, але й на види. Ваги цих проекцій вказують на тенденції, які характеризуються часовою динамікою, притаманні тому або іншому виду. А отже, кластеризація видів на основі ССА-осей дозволяє провести їх класифікацію за ознакою типових особливостей динаміки. Ієрархічний кластерний аналіз вказує на те, що серед досліджених видів без хребетних можна виділити чотири кластери, які досить однорідні стосовно головних патернів часової динаміки (рис. 4). Кращі результати за критерієм гомогенності кластерів дав метод $k$ середніх. Відображення кластерів у просторі оцінок оптимумів і толерантності видів надав можливості змістовно інтерпретувати кластери як сукупності весняних, літніх, літньо-осінніх та осінніх видів. За оцінками оптимуму видів за методом ССА-підходу весняні види характерризуються найвищими значеннями оцінок, літні та літньо-осінні майже не розрізняються, а осінні характеризуються найменшими оцінками оптимальності.

Оцінки за методом зважених середніх дають менш чітку картину розподілу оцінок оптимумів по кластерах, що свідчить про те, що часові патерни, на основі яких встановлені кластери, зазнають суттєвих зсувів уздовж осі часу під впливом факторів середовища або міжвидових взаємодій. За оцінками толерантності ССА-підхід вказує на те, що найбільш толерантні весняні види, а інші групи безхребетних є більш спеціалізованими. За
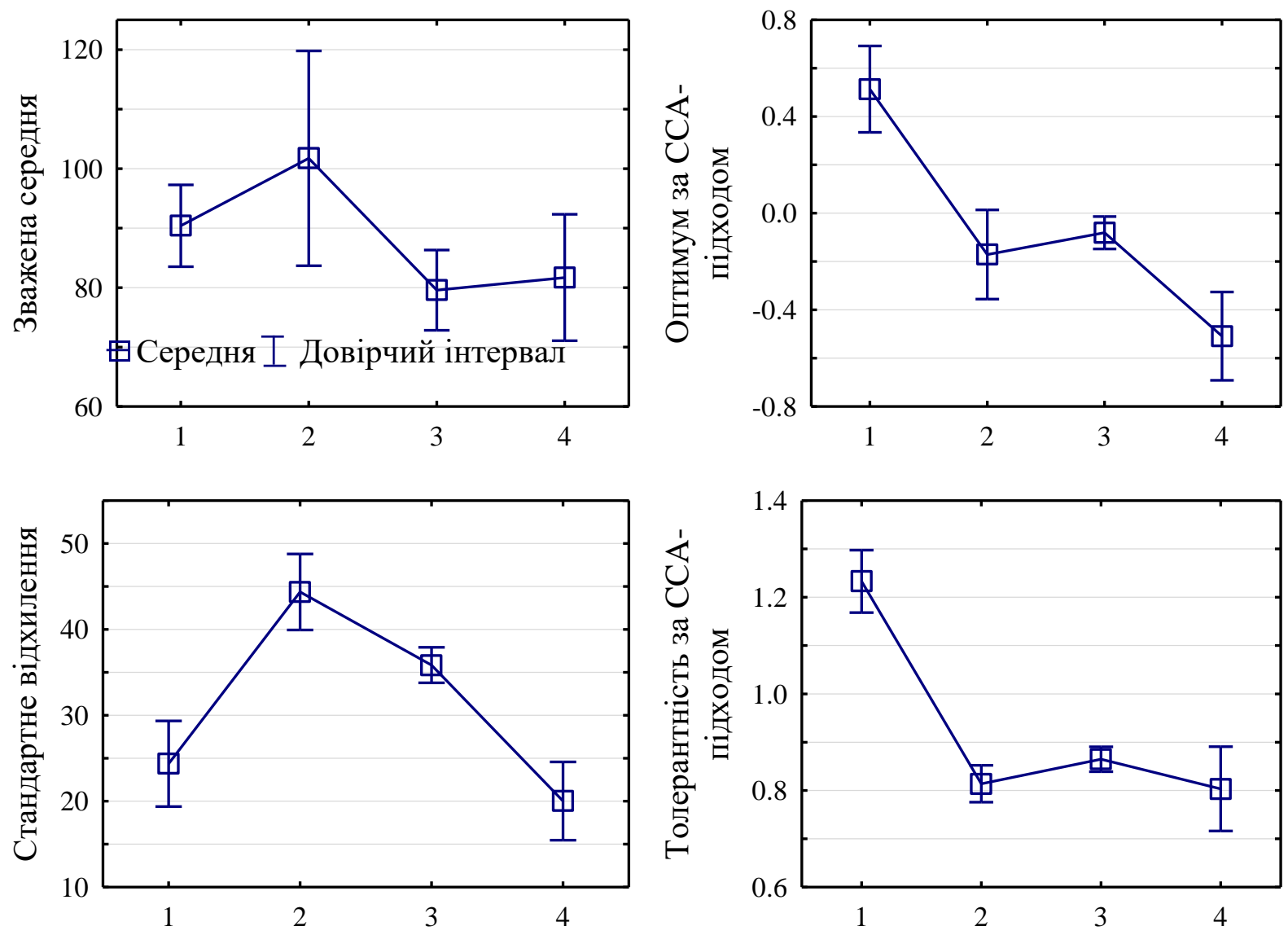

Рис. 4. Очінки за різними підходами оптимумів і толерантності видів у градієнті часу для екологічних груп тварин. Ось абсцис - екологічні групи (кластери): 1 - весняні, 2 -літні; 3 -літньоосінні; 4 -осінні 


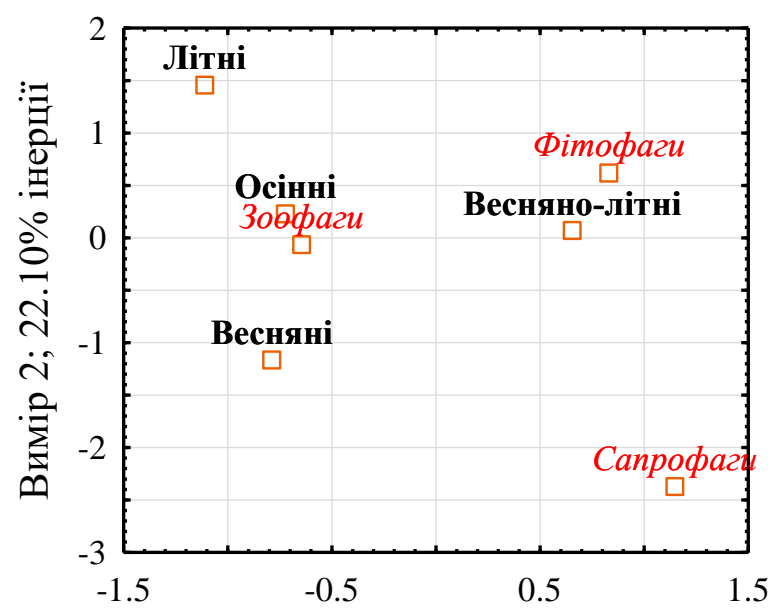

Вимір 1; 23.10\% інерції

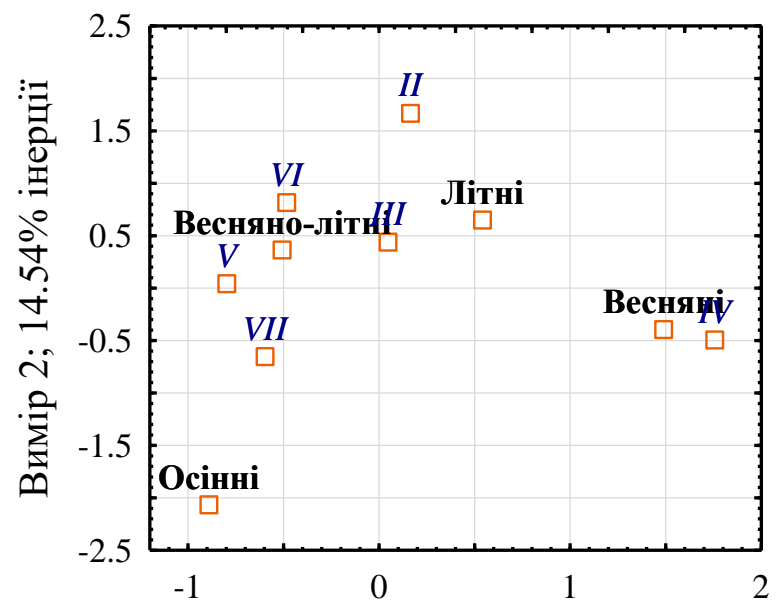

Вимір 1; 18.07\% інерції

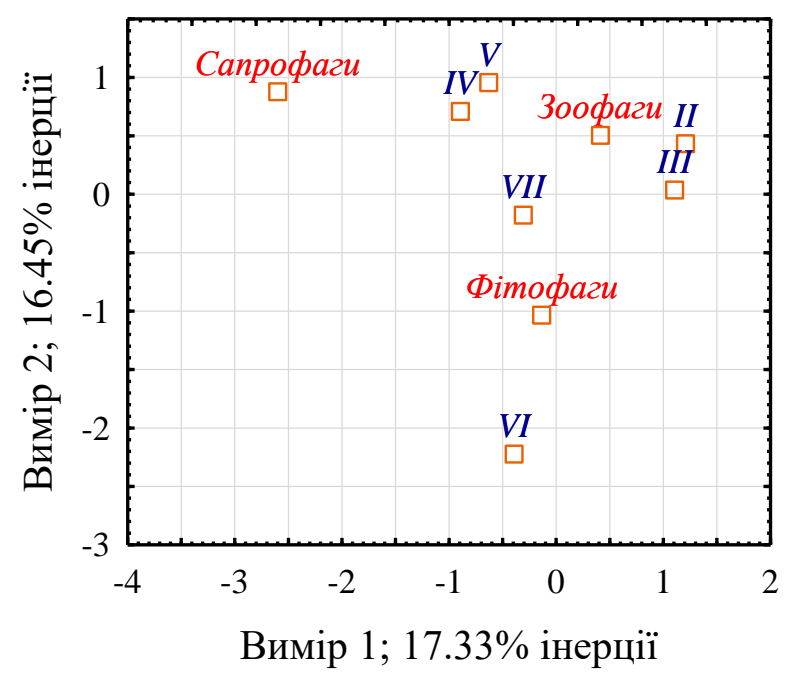

Рис. 5. Множинний аналіз відповідностей сезонних груп безхребетних тварин, моделей відгуків і трофічних груп. II-VII - типи моделей Хуізмана, Ольфа та Фреско

методом середнього зваженого найбільш толерантні літні та літньо-осінні види, а весняні та осінні є більш спеціалізованими.
Множинний аналіз відповідностей дозволив встановити, що сезонні групи мають свою специфіку з погляду на їх трофічну структуру (рис. 5).

Фітофаги переважають серед літньо-осінніх форм, а зоофаги - серед осінніх та меншою мірою серед весняних або літніх. Для сапрофагів не встановлено переважання в тій або іншій сезонній групі. Відгук літніх форм у градієнті часу найчастіше описується симетричною дзвіноподібною моделлю V. Літньо-осінні форми характеризуються відгуками на час, які можуть бути описані моделями V, VI та VII. Весняні форми найчастіше мають розподіл, який найкраще описується моделями II та III. Для літніх форм характерна модель VII. Фітофаги найчастіше мають відгук на градієнт часу, який найкраще може бути описаний моделями II та III, фітофаги - VI та VII, сапрофаги - IV та V.

Отже, одержані результати значно розширюють наші уявлення про закономірності динаміки угруповань тварин на штучно створених грунтоподібних тілах - техноземах. Раніше було показано, що угруповання грунтової макрофауни техноземів формують просторово регулярні патерни [45, 49]. Одержані результати вказують на наявність часових патернів. Також нам удалось підійти до вирішення питання про механізми, які визначають просторову й часову регулярність популяцій та угруповань безхребетних в антропогенних екосистемах.

\section{ВИСНОВКИ}

Динаміка в часі протягом вегетаційного сезону чисельності найбільшої кількості видів безхребетних ділянки рекультивації описується бімодальною асиметричною моделлю (модель VII 3 переліку HOFJO). Бімодальність підкреслює важливість впливу біотичних (конкурентних) взаємодій між видами. Бімодальність може бути наслідком біологічної неоднорідності популяції та результатом міграційних процесів. Встановлені типи часової динаміки безхребетних вказують на наявність складних та сформованих процесів регулювання чисельності тварин на порівняно молодих екологічних утвореннях, якими $\epsilon$ техноземи. Часова динаміка видів безхребетних структурована в просторі та характеризується наявністю регулярних часових патернів, на основі яких встановлені такі фенологічні групи тварин: весняні, літні, літньо-осінні та осінні. Фітофаги переважають серед літньо-осінніх 
Часова динаміка видів безхребетних в техноземах Нікопольського марганиеворудного басейну

форм, а зоофаги - серед осінніх та меншою мірою серед весняних або літніх. Відгук літніх форм у градієнті часу найчастіше описується симетричною дзвіноподібною моделлю $\mathrm{V}$. Літньо-осінні форми характеризуються відгуками на час, які можуть бути описані моделями V, VI та VII. Весняні форми найчастіше мають розподіл, який найкраще описується моделями II та III. Для літніх форм характерна модель VII.

\section{ЛITЕРАТУРА}

1. Austin, M. P. A silent clash of paradigms: some inconsistencies in community ecology. Oikos; 1999, 86(1), 170-178. DOI: 10.2307/3546582

2. Bonato, L.; Minelli, A.; Lopresti, M. ChiloKey, an interactive identification tool for the geophilomorph centipedes of Europe (Chilopoda, Geophilomorpha). ZooKeys; 2014, 443, 1-9.

3. Borcard, D.; Legendre, P.; Avois-Jacquet, C.; Tuosimoto, H. Dissecting the spatial structure of ecological data at multiple scales. Ecology; 2004, 85, 1826-1832.

4. Brandle, M.; Durka, W.; Krug, H., Brandl, R. The assembly of local communities: plants and birds in non-reclaimed mining sites. Ecography; 2003, 26, 652660. DOI: 10.1034/j.1600-0587.2003.03513.x

5. Brown, J. H. Macroecology: progress and prospect. Oikos, 2003, 87, 3-14. DOI: 10.2307/3546991

6. Buchori, D.; Rizali, A.; Rahayu, G. A.; Mansur, I. Insect diversity in post-mining areas: Investigating their potential role as bioindicator of reclamation success. Biodiversitas; 2018, 19, 16961702. DOI: $10.13057 /$ biodiv/d190515

7. Chase, J. M.; Myers, J. A. Disentangling the importance of ecological niches from stochastic processes across scales. Philosophical Transactions of the Royal Society B: Biological Sciences; 2011, 366, 2351-2363. https://doi.org/10.1098/rstb.2011.0063

8. Cherny, N. G.; Golovach, S. I. Millipedes of the plain territories of Ukraine. Kiev. 1993.

9. Colwell, R. K.; Futuyma, D. J. Measurement of niche breadth and overlap. Ecology; 1971, 52, 567-576. DOI: $10.2307 / 1934144$

10. Desender, K.; Ervinck, A.; Tack, G. Beetle diversity and historical ecology of woodlands in Flanders. Belgian Journal of Zoology;.1999, 129(1), $139-155$.

11. Devictor, V.; Clavel, J.; Julliard, R.; Lavergne, S.; Mouillot, D.; Thuiller, W.; Venail, P.; Villéger, S.; Mouquet, N. Defining and measuring ecological specialization. Journal of Applied Ecology; 2010, 47, 15-25. doi:10.1111/j.1365-2664.2009.01744.x

12. Dunger, W.; Wanner, M.; Hauser, H.; Hohberg, K.; Schulz, H.-J.; Schwalbe, T.; Seifert, B.; Vogel, J.; Voigtländer, K.; Zimdars, B.; Zulka, K.P. Development of soil fauna at mine sites during 46 years after afforestation. Pedobiologia; 2001, 45(3), 243-271. https://doi.org/10.1078/0031-4056-00083.
13. Elton, C. Animal Ecology. Sidgwick and Jackson, London. 1927.

14. Entling, W.; Schmidt, M. H.; Bacher, S.; Brandl, R.; Nentwig, W. Niche properties of Central European spiders: shading, moisture and the evolution of the habitat niche. Global Ecology and Biogeography; 2007, 16, 440-448. doi:10.1111/j.1466-8238.2006.x

15. Gaston, K. J.; Blackburn, T. M.; Lawton, J. H. Interspecific abundance-range size relationships: an appraisal of mechanisms. Journal of Animal Ecology; 1997, 66(44), 579-601. DOI: 10.2307/5951

16. Ge B.; Daizhen, Z.; Jun, C.; Huabin, Z.; Chunlin, Z.; Boping, T. Biodiversity Variations of Soil Macrofauna Communitiesin Forestsina Reclaimed Coastwith Different Diked History. Pakistan Journal of Zoology; 2014, 46(4). 1053-1059.

17. Gregory, R. D.; Gaston, K. J. Explanations of commonness and rarity in British breeding birds: separating resource use and resource availability. Oikos; 2000, 88, 515-526. https://doi.org/10.1034/j.16000706.2000.880307.x

18. Grinnell, J. The niche relationship of the California Thrasher. The Auk: Ornithological Advances; 1917. 34(4), 427-433. https://doi.org/10.2307/4072271

19. Gural-Sverlova, N. V.; Gural, R. I. Identification book of the terrestrial molluscs of Ukraine. Lviv. 2012.

20. Hedde, M.; Nahmani, J.; Séré, G.; Auclerc, A.; Cortet J. Early colonisation of constructed technosols by macro-invertebrates. Journal of Soils and Sediments; 2018, 19(8), 3193-3203. https://doi.org/10.1007/ s11368-018-2142-9

21. Hendrychova, M. Reclamation success in postmining landscapes in the Czech Republic: a review of pedological and biological studies. Journal of Landscape Studies; 2008, 1, 63-78.

22. Hendrychova, M.; Salek, M.; Tajovsky, K.; Reho, M. Soil properties and species richness of invertebrates on afforested sites after brown coal mining. Restoration Ecology; 2011, 20 (5), 561-567. https://doi.org/10.1111/j.1526-100X.2011.00841.x

23. Hildmann, E.; Wunsche, M. Lignite mining and its after-effects on the central German landscape. Water, Air and Soil Pollution; 1996, (91), 79-87. DOI https://doi.org/10.1007/BF00280924

24. Hodecek, J.; Kuras, T.; Sipos, J.; Dolny, A. Post-industrial areas as successional habitats: long-term changes of functional diversity in beetle communities. Basic and Applied Ecology, 2015. 16(7), 629-640. https://doi.org/10.1016/j.baae.2015.06.004

25. Hodecek, J.; Kuras, T.; Sipos, J.; Dolny, A. Role of reclamation in the formation of functional structure of beetle communities: A different approach to restoration. Ecological Engineering; 2016, 94, 537-544. https://doi.org/10.1016/j.ecoleng.2016.06.027

26. Hutchinson, G. E. Concluding remarks. Cold Spring Harbour Symposium on Quantitative Biology; 1957, 22, 415-427. http://dx.doi.org/10.1101/SQB. 1957.022.01.039

27. Identification key to the insects of the European part of the USSR in five volumes (edited by Corresponding Member of the USSR Academy of 
Sciences G.Ya.Bey-Bienko). Volume 2. Beetles and Strepsiptera. Volume Editors: EL Guriev and OL Kryzhanovsky. ("Identification keys to the fauna of the USSR Academy of Sciences of the USSR published by the Zoological Institute", vol. 89) Publishing House "Science". Moscow - Leningrad. 1965.

28. Jansen, F.; Oksanen, J. How to model species responses along ecological gradients - Huisman-OlffFresco models revisited. Journal of Vegetation Science; 2013, 24, 1108-1117. https://doi.org/10.1111/jvs.12050

29. Kędzior, R. Co-occurrence pattern of ground beetle (Coleoptera, Carabidae) indicates the quality of restoration practices in postindustrial areas. Applied Ecology and Environmental Research; 2018; 16(6), 7913-7924. DOI: http://dx.doi.org/10.15666/aeer/ 1606_79137924

30. Kielhorn, K. H.; Keplin, B.; Hüttl, R. F. Ground beetle communities on reclaimed mine spoil: Effects of organic matter application and revegetation. Plant and Soil; 1999, 213(1-2), 117-125. https://doi.org/10.1023/A:1004508317091

31. Klimkina, I.; Kharytonov, M.; Zhukov, O. Trend Analysis of Water-Soluble Salts Vertical Migration in Technogenic Edaphotops of Reclaimed Mine Dumps in Western Donbass (Ukraine). Journal of Environmental Research, Engineering and Management; 2018, 74 (2), 82-93. http://dx.doi.org/ 10.5755/j01.erem.74.2.19940

32. Kohn, A. J. Microhabitats, abundance, and food of Conus in the Maldive and Chagos Islands. Ecology; 1968, 49, 1046-1061. https://doi.org/ $10.2307 / 1934489$

33. Kunah, O. M.; Zelenko, Y. V.; Fedushko, M. P.; Babchenko, A. V.; Sirovatko, V. O.; \& Zhukov, O. V. The temporal dynamics of readily available soil moisture for plants in the technosols of the Nikopol Manganese Ore Basin. Biosystems Diversity; 2019, 27(2), 156-162. doi:10.15421/011921

34. Lawton, J. H. Are there general laws in ecology?; 1999, 84, 177-192. DOI: $10.2307 / 3546712$

35. Michaelis J.; Diekmann, M.R. Biased niches Species response curves and niche attributes from Huisman-Olff-Fresco models change with differing species prevalence and frequency. PLoS ONE; 2017, 12(8), e0183152. https://doi.org/10.1371/journal. pone. 0183152

36. Okie, J. G.; Van Horn, D. J.; Storch, D.; Barrett, J. E.; Gooseff, M. N.; Kopsova, L.; \& TakacsVesbach, C. D. Niche and metabolic principles explain patterns of diversity and distribution: theory and a case study with soil bacterial communities. Philosophical Transactions of the Royal Society B: Biological Sciences; 2015, 282, 2014, 2630. http://dx.doi.org/ 10.1098/rspb. 2014.2630

37. Oksanen, J.; Blanchet, F. G.; Kindt, R.; Legendre, P.; Minchin, P. R.; O’Hara, R. B.; Simpson,
G. L.; Solymos, P.; Stevens, M. H.; Wagner, H. Community Ecology Package. $R$ package version 2.5-2; 2018, https://CRAN.R-project.org/package=vegan

38. Pontegnie, M.; du Bus de Warnaffe, G.; Lebruna, $\mathrm{Ph}$. Impacts of silvicultural practices on the structure of hemi-edaphic macrofauna community. Pedobiologia; 2005, 49(3), 199-210. DOI: 10.1016/j.pedobi.2004.09.005

39. Rehor, M.; Lang, T.; Eis, M. Application of new methods in solving current reclamation issues of Severoceske doly, a.s. localities. World of Surface Mining; 2006, 6, 383-386.

40. Schoener, T. W. Resource partitioning in ecological communities. Science; 1974, 185(4145), 2739.

41. Sklenicka, P.; Prikryl, I.; Svoboda, I.; Lhota, T. Non-productive principles of landscape rehabilitation after long-term opencast mining in north-west Bohemia. Journal of the South African Institute of Mining and Metallurgy; 2004, 104, 83-88.

42. Soberon, J. Grinnellian and Eltonian niches and geographic distributions of species. Ecology Letters; 2007, 10(12), 1115-1123. https://doi.org/10.1111/j. 1461-0248.2007.01107.x

43. Szczepanska, J.; Twardowska, I. Distribution and environmental impact of coal-mining wastes in Upper Silesia Poland. Environmental Geology; 1999, 38, 249-258. DOI https://doi.org/10.1007/ s002540050422

44. Tarjuelo, R.; Morales, M. B.; Arroyo, B.; Mañosa, S.; Bota, G.; Casas, F.; Traba, J. Intraspecific and interspecific competition induces density-dependent habitat niche shifts in an endangered steppe bird. Ecology and evolution; 2017, 7 (22), 9720-9730. doi:10.1002/ece3.3444

45. Yorkina, N.; Maslikova, K.; Kunah, O.; Zhukov, O. Analysis of the spatial organization of Vallonia pulchella (Muller, 1774) ecological niche in Technosols (Nikopol manganese ore basin, Ukraine). Ecologica Montenegrina; 2018, 17, 29-45.

46. Zalesskaya N. T. Identification key of centipedes USSR. Nauka: Moscow, 1978.

47. Zalesskaya, N. T.; Shileiko, A. A. Scolopendra centipedes. Nauka: Moscow, 1991.

48. Zhenqi, H.; Peijun, W.; Jing, L. Ecological Restoration of Abandoned Mine Land in China. Journal of Resources and Ecology; 2012, 3 (4), 289-296. DOI:10.5814/j.issn.1674-764x.2012.04.001

49. Zhukov O. V.; Zadorozhna, G. O.; Maslikova K. P.; Andrusevych K. V.; Lyadskaya I. V. Tehnosols Ecology. Zhurfond: Dnipro. 2017.

50. Zhukov, O. V.; Maslikova, K. P. The dependence of the technosols models functional properties from the primary stratigraphy designs. Journal of Geology, Geography and Geoecology; 2018, 27 (2), 399-407. doi:10.15421/111864 